\title{
Program Coordination and Synergy of the Foreign Supervision Team (Tim Pora) in Cianjur Regency
}

\author{
Rachmat \\ Sekolah Tinggi Ilmu Sosial dan Ilmu Politik Guna Nusantara, Cianjur, Indonesia \\ *Coresponding Author \\ Email: 65rachmat@gmail.com

\begin{abstract}
.
This study aims to find (identify) and determine problems related to the arrival of foreigners in Cianjur Regency. Furthermore, this research wants to set goals to be achieved. Of course, with the formation of the Pora Team, we want cooperation and coordination as well as synergy between related agencies. Third, the purpose of this study was to determine the communication strategy of the Pora Team in order to deal with the presence and activities of foreigners in the Cianjur Regency area. This study uses a qualitative approach with a post-positivistic paradigm. The method used is a case study. The models used are Assifi and French models. The result of this research is that the Pora Team analyzed various cases related to foreigners who came to Indonesia, especially Cianjur. The Sukabumi Class II Immigration Office released data on the number of Foreign Citizens (WNA) holding Permanent Stay Permit Cards (KITAP) who reside and have activities in Sukabumi and Cianjur. Apart from mixed marriages, not a few foreigners have the status of workers. There are 65 foreigners holding KITAP Cianjur Regency. The purpose of establishing the Pora Team is to supervise foreigners who come to Cianjur Regency, as an effort to prevent violations of regulations by foreigners in Cianjur Regency. The Pora Team's strategy-setting activities cover a variety of activities. These activities are in the form of (1) audience analysis, (2) selecting media, (3) developing messages, (4) implementing programs, (5) conducting monitoring and evaluation. The audience analysis in this case is foreigners. These foreigners have various kinds of arrival purposes such as tourism, socio-cultural visits, government, social and even for work. The Pora team in carrying out their duties collaborates with the Media. The Pora team coordinates with various government organizations. In carrying out its programs, apart from carrying out the duties and functions of the Pora Team, it can also carry out joint operations if needed. In conducting monitoring and evaluation, the results of joint operations are reported directly in writing. The report is submitted to the Chairman of the Pora Team no later than 7 (seven) days from the time the joint operation was carried out. The Pora team also has a map of the supervision of foreigners, solving problems of the existence and activities of foreigners, implementing and regulating relations and cooperation in the framework of controlling foreigners, preparing joint operation plans that are special or incidental in nature.
\end{abstract}

Keywords: Coordination, Synergy, and Tim Pora

\section{INTRODUCTION}

We understand that the position of Indonesia is very strategic make Indonesia the place of destination and transit for the traffic of people and goods. In addition to providing a positive impact, the potential existence of traffic of people, especially the Citizens of a Foreign Country can carry other interests are not responsible for such as for example the rise of human trafficking (human trafficking), human smuggling (people smugling), traffic illegal goods (drugs, psychotropic substances) as well as the interest charged ideological, political, economic, social culture that can threaten the stability of the country. Immigration office Class II Sukabumi released data on the number of Foreign Citizens the owner of the Card Permanent Stay Permit who settled and day in Sukabumi and Cianjur. In addition to the mixed marriage, not a few Foreigners whose status as workers. There are 134 WNA holder KITAP which is divided in Sukabumi Regency as many as 51 people, Districts Cianjur 65 people and the City of Sukabumi 18 people.

Based on the problem and the data, then the Immigration Office Class II Non TPI Sukabumi form a Team the Supervision of a Stranger (Team Pora) the level of districts and Sub-Districts in the region of Cianjur. Team Pora consisting of forkopimda which elements of the government of the District of Cianjur, Police, Military, and related ministries/agencies. The formation of the Team Pora level of districts and SubDistricts is done on the basis of Article 69 of Law No. 6 of 2011 on Immigration as well as the socialization 
of the supervision of strangers is followed by 57 participants. The purpose of the formation of the Team Pora is to enhance cooperation and coordination and synergy between the agencies involved in the supervision of the existence and activities of foreigners in each region. The formation of the Team Pora to give a sense of security, both to the existence of a foreign citizen itself, and the community. The task Team Pora is to provide advice to the leadership of the agencies in terms of the existence and activities of foreigners in each region. The existence of the Strangers that do a variety of activities in the territory of the laws of Indonesia need to get the attention of all parties. Therefore, coordination between the relevant agencies in order perception in terms of supervision of the activities of the Foreigners that are currently accommodated in the Team Pora at the level of districts and Sub-Districts absolute do.

Based on such exposure, this study aimed to find (identify) and assign issues related to the arrival of a stranger in Cianjur. Next is this research want to set a goal to be achieved. Of course with the formation of the Team Pora want to so there is cooperation and coordination and synergy between the relevant agencies. Third, the Purpose of this study is to establish the communication strategy Team Pora in order to deal with the existence and activities of foreigners in the territory of Cianjur Regency.

\section{METHODS}

This study uses a qualitative approach with the paradigm of a post-positivistic. Qualitative methods more emphasis on the observation of phenomena and is researching into the substance of the meaning of the phenomenon. Analysis and sharpness of qualitative research is highly affected on the power of words and sentences used. Therefore, Basri (2014) concluded that the focus of qualitative research is on the process and meaning of the result. Attention to qualitative research is more focused on the human elements, objects, and institutions, as well as the relationship or the interaction among these elements, in an effort to understand an event, behavior, or phenomenon (Mohamed, Abdul Majid \& Ahmad, 2010). As for the technique used is a case study. Yin (1994: 21) is not enough if the Case Study questions only asked "what", (what), but also "how" (how) and "why" (why). The question of "what" is intended to acquire knowledge descriptive (descriptive knowledge), "how" (how) to acquire knowledge explanative (explanative knowledge), and "why" (why) to acquire knowledge of exploratory (explorative knowledge). Yin emphasizes the use of the question of "how" and "why", because the second question is considered very appropriate for obtaining deep knowledge about the symptoms studied. In addition, the form of the question will determine the strategy used to obtain the data. The Model used is a model Assifi and French. This Model was created in 1982 (Nasution; 1994). This Model begins with; (1) problem analysis, and (2) communication strategies, namely (analysis of audiences, setting goals, choosing media, developing book, producing media, implement the program, monitoring and evaluation).

\section{RESULT AND DISCUSSION}

The first step to perform activities of communication programs that have been planned by a Team of Revelry which begins with the discovery of the problem. Without finding the problem then the activities carried out can be an act of extravagance, even works without problems can be likened to walking without direction. The problem is the difference between expectations and reality, or the difference between aspiration and reality. To find a problem it is necessary facts (Cangara, 2014).

\section{Stages Of Problem Analysis}

Team Pora analyze a variety of cases related to foreign entrants who come to Indonesia, especially in Cianjur. Immigration office Class II Sukabumi released data on the number of Foreign nationals (foreigners) the owner of the Card Permanent Stay Permit (KITAP) who settled and day in Sukabumi and Cianjur. In addition to the mixed marriage, not a few Foreigners whose status as workers. There are 134 WNA holder KITAP which is divided in Sukabumi Regency as many as 51 people, Kabupaten Cianjur 65 people and the City of Sukabumi 18 people. Recorded Foreigners from China amounted to 32 people, South Korea 21 
people, saudi Arabia is 9 people, Pakistan is 7 people, the Netherlands 6 people, Australia and Bangladesh each 5 people. Then the Foreigner national of the United States 4 people, Germany, Yemen, India, Kuwait, Singapore and Malaysia each 3 people. WNA Philippines, France, United Kingdom, Russia, Brazil and Syria respectively 2 people. In addition, FOREIGN citizens of Afghanistan, Iran, Tunisia, Palestine, Cameroon, hong kong, Turkey, Sudan, South Africa, Czech Republic, Canada, Comoros, Egypt, New Zealand and Taiwan 1 person each. From the number 134 was, 108 of them in the because the unification of a diverse family of factors ranging from mixed marriage, children come with parents, the elderly and many more. Then the rest or 26 people status as workers (foreign). Immigration office Class II Sukabumi released data on the number of Foreign nationals (foreigners) the owner of the Card Permanent Stay Permit (KITAP) who settled and day in Sukabumi and Cianjur. Of the 134 Foreigners Settled in Sukabumi-Cianjur, Only 42 People Have e-ID card. Another problem that has surfaced is of foreign workers (TKA) illegally captured Supervision Team of Strangers (Tim Pora) Cianjur, during a raid in one of the mining companies in District Cikalong. By knowing the issues, then the Team Pora able to plan a program of communication can set a goal. Destination is a state or desired changes after the implementation of the plan. In setting goals, a planner of communication should be able to answer the question; why do You need to perform communication activities and what you want to accomplish with these activities? Change how you want? After that proceed with the question of whether the objectives to be achieved in accordance with the needs of the target (need assessment)?. That to implement the provisions in Article 201 of Government Regulation No. 31 of 2013 of the implementing Regulations of Law No. 6 of 2011 on Immigration, as amended by Government Regulation No. 26 of 2016 on the amendment of Government Regulation No. 31 of 2013 of the implementing Regulations of Law No. 6 of 2011 on Immigration, need to set a Regulation of the Minister of Law and Human Rights on the Surveillance Team of Strangers.

Regulation of the minister of law and human rights Republic of Indonesia No. 50 of 2016 about the Team the supervision of foreigners stating that what is meant by: (1) the Stranger is a person who is not a citizen of Indonesia. (2) the Supervision Team Stranger hereinafter referred to as the Team Pora is a team consisting of agencies and/or government agencies that have duties and functions associated with the presence and activities of Strangers. (3) the Territory of the Republic of Indonesia, which then called the Territory of Indonesia is the entire Territory of Indonesia as well as a particular zone defined by law. (4) the minister is the Minister who held government affairs in the field of law and human rights. (5) the Director General is the Director General of Immigration.Pembentukan Tim Pora dimaksudkan untuk mewujudkan pengawasan keimigrasian yang terkoordinasi dan menyeluruh terhadap keberadaan dan kegiatan Orang Asing di Wilayah Indonesia. Tim Pora dibentuk di tingkat pusat dan tingkat daerah. Pembentukan Tim Pora dilaksanakan setiap tahun. The purpose of the formation of the Team Pora is to keep an eye on foreigners who come to the Cianjur Regency, in an effort to prevent violations of the regulations by a stranger in Cianjur Regency, one of which is to promote the Surveillance Team of Strangers (Tim Pora) from the central, provincial, district/town up to the district level, where the Team Pora involves all elements of the government.

The task Team Pora is to provide advice to the agency and/or government agencies, for matters relating to the Supervision of Strangers. In carrying out the task Team Pora has the following functions: a. coordination and exchange of data and information; $b$. the collection of information and data in the presence of Strangers in stages from the village or village level up to the province; c. analysis and evaluation of data/information related to the implementation of the Supervision of Foreigners as well as making the map the Supervision of Foreigners d. solving the problem of the existence and activities of Foreigners; e. the implementation and regulation of relations as well as cooperation in the framework of the Supervision of Foreigners; f. the preparation of a plan of combined operations that are special or incidental damages include the plan of operation independent of each agency Team members Pora; and g. implementation of other functions assigned by the Team leader Pora related to the Supervision of Strangers. 


\section{Stage Communication Strategy Team Pora}

The determination of the strategy is a step crucial that require handling of caution in any program of communication. For if the determination of the strategy wrong or mistaken then the path traveled can fail, especially losses in terms of time, material, and labor. The strategy also is to be secured by the expert planning of communication. The activities of setting the strategy of the Team Pora includes a wide variety of activities. Activities in the form of (1) the analysis of the audience, (2) choose media, (3) develop the message, (4) implement the program, (5) monitoring and evaluation. Team meeting Pora Administrative Region Cianjur this is followed by some government agencies, such as the forkopimda which elements of the government of the District of Cianjur, Police, MILITARY, and related ministries/agencies. Team activities Pora also held a press conference as the socialization of the program Team Pora in Cianjur. The analysis of the audience in this case is a stranger. This stranger has a wide range of goals coming as a tourist, visit social culture, government, social and even to work. And of the various problems that arise related to the existence and activities of foreigners. It is feared would have a negative impact on various aspects such as social aspects, security and order, religious, until the issue of employment. However, the function of the Team Pora in particular is that the coordination and exchange of data and information, collection of information and data in the presence of strangers in stages, analysis and evaluation of data/information related to the implementation of the supervision of foreigners in Cianjur.

Team Pora in carrying out their duties to cooperate with the Media. Team Pora also do a press release and together with the press row socialize formation and carry out the programs Team Pora. Media-media that work together with a Team of Pora is a specialized online and offline. They held a press conference, interview, and also together with the media surveyed the stranger to the various regions. Come and records is one of the tasks of the Team Pora. Team Pora level is vertical, i.e. levels of the area consist of: a. Team Pora provincial level; b. Team Pora district/city level; and c. Team Pora sub-district level. In certain cases, the Head of the Immigration Office can form a Team Pora at the Immigration checkpoint. The Central Level Pora team was formed with The Minister's Decision. The Central level Pora team is managed by The Director of Supervision and Pensions To The Pedigrasian, Directorate General of Immigration, Ministry of Law and Human Rights. The Provincial Level Pora team was formed with The Decision Of Head of The Territorial Office Of The Ministry Of Law and Human Rights. The Provincial Level Pora team is managed by The Head of The Keimigrasian Division of The Area Office of The Ministry of Law and Human Rights. The County/city level Pora team, and districts formed With The Decision of The Head Of The Immigration Office. The Team Is a county/city level, and the district is managed By The Head Of The Immigration Office. The Pora team provided representation from the agencies and/at the baik government institution at the maupun center in the regional.

The Structure of The Pora level center team organization is relegated to: a. b; b. chairman; c. secretary; dan d. members. The Structure of The Regional Level Pora team organization is relegated to: a. Team Pora provincial level: 1 . advisors; 2 . chairman; 3. secretary; dan 4. members. b. Team Pora county / city level: 1. advisors; 2. chairman; 3. secretary; dan 4. members. c. Team Pora district level: 1. chairman; 2. secretary; dan 3. members. Members Of The Pora team of the highest center level are relegated from element: a. Ministry of Law and Human Rights; b. Ministry of Foreign Affairs; c. Ministry of Foreign Affairs; d. Ministry of Tourism; e. Indonesian National army; f. Kekol, Republic Of Indonesia; g. Great championship; h. Ministry of Finance; i. Ministry Of Health; j. Ministry of Fame; k. Ministry of Religion; 1. Ministry of Marine And Fisheries; m. Ministry Of Education and Subculture; n. Ministry of Technology Research and High Education; o. Social ministry; p. Ministry of Transportation; q. Ministry of Youth and Sport; $r$. Ministry of State Secretariat; s. Indonesian science institution; t. State Intelection bodies; u. National Narcotics bodies; v. Strategic Intelection body TNI; w. Navy Security bodies; and x. The National Body For Terrorism Reduction. Members of The Provincial level Pora team are most of the elements: a. Area office of Ministry Of Law and Human Rights; b. Regional keepers; c. Provincial Regional government; d. Provincial National Narcotics bodies; e. Regional State Intelection bodies; f. Military Regional command/Military 
Resort Command; g. Main air hub of The Air Force; h. Command Major Workstation of The Navy; i. High championship; and j. Office Area Taxes.

Team members Pora district/city level, at least consist of the elements: a. Immigration office; b. Police Resort City/Police Resort; c. State prosecutor; d. The government of regency/city; e. Badan Narkotika Nasional kabupaten/kota; f. The State Intelligence agency of the Region; g. Command of the Military District; h. Naval base/Naval; and i. Air Base Air Force. Team members Pora sub-district level at least consist of the elements: a. Immigration office; b. Police Sector; c. Komando Rayon militer d. The government of the District; and e. The village or Village Government. In carrying out its programs, in addition to carrying out duties and functions of the Team Pora can also perform a merge operation if necessary. The merge operation can be either: $a$. the combined operation of a special nature; or b. a joint operation that is incidental. The merge operation as performed based on the operation plan. A joint operation is an operation performed on a time or a particular activity. The merge operation which is incidental is an operation that is performed at any time in the event of any of the report: a. the community; and/or b. Team members Pora. The merge operation is performed at least 2 (two) times in 1 (one) year, based on the results of the working meeting of the Teams Pora to pay attention to the budget availability. In the implementation of a joint operation, each member of the Team Pora send members with a number of in accordance with the agreement in the meeting of the working Team Pora. A joint operation is usually led by the immigration officials are appointed. In terms of the results of a joint operation to find Foreigners who violate the provisions of laws and regulations, the Team Pora submit a Stranger to the relevant authorities.

In monitoring and evaluation, the results of the merge operation immediately reported in writing. The report least contain: a. the base implementation; b. personnel; c. time and place of execution; $d$. chronological order of implementation; e. the results achieved; and $\mathrm{f}$. conclusions and suggestions. The report is submitted to the Chairman of the Team Pora later than 7 (seven) days since the merge operation is implemented. Team leader Pora submit the report referred to: a. The director General for the Team Pora center; or b. The director of the Supervision and Enforcement of the Immigration, Directorate General of Immigration, Ministry of Law and Human Rights for the Team Pora area. To support the implementation of the tasks and functions of the administration Team Pora, the Chairman of the Team Pora can form the secretariat. Team Pora this also has a map of the supervision of foreigners, the settlement of the problems of the existence and activities of foreigners, implementation and regulation of relations as well as cooperation in the framework of the supervision of strangers, the preparation of the plan of combined operations of a special nature or are incidental. Including a plan of operation independent of each agency Team members Revelry, and the implementation of other functions assigned by the Team leader Pora related to the supervision of strangers. In addition in order to streamline the supervision of a stranger, the Team PORA along with the Director general of Immigration also create a Reporting Application of Strangers (APOA), it is used to keep an eye on foreigners who reside or stay in a place of lodging. This is also related to the enforcement of ACT No. 6 of 2011 on Immigration Article 72 (2) requiring the owner or caretaker of the place of stay is required to provide data about foreigners staying in the best place to stay. With APOA this then all the activities of the management of the stay will be reported online and facilitate the owner or manager of the inn report online stranger staying in place, and the Director general of Immigration also take advantage of the QR Code technology in order to increase the scrutiny of strangers.

Every stranger who comes to Cianjur after going through their immigration process on-site inspection of immigration, in his passport will be given a sticker containing a barcode that contains data the immigration people. Through a special application QR Code reader, Immigration officers can display the necessary data in the screen of the smartphone officers and transmit the position of the location of the scan, so that location data can be used to calculate the presence of strangers and monitor its movement. Immigration office routinely conduct surveillance activities against the existence and activities of foreigners in the jurisdiction in Cianjur. So far from the activities of the supervision of foreigners has found multiple violations by a stranger who immediately followed up with the immigration enforcement in accordance with 
the immigration rules. Administrative action on Immigration one of the forms of law enforcement to a stranger over the various forms of violations of immigration done.

\section{REFERENCES}

[1] Basri, H. (2014). Using qualitative research in accounting and management studies: not a new agenda. Journal of US-China Public Administration, October 2014, Vol.11, No.10, 831-838. DOI: 10.17265/15486591/2014.10.003

[2] Cangara. (2014). Perencanaan dan Strategi Komunikasi. Jakarta: Rajawali Pers.

[3] https://news.detik.com/berita-jawa-barat/d-4448270/134-wna-menetap-di-sukabumi-cianjur-hanya-42-orangpunya-e-ktp.

[4] http://kanimsukabumi.kemenkumham.go.id/artikel-92-kakanwil-sitinjak-kukuhkan-timpora-tingkat-kabupatendan-kecamatan-di-cianjur.html

[5] https://www.liputan6.com/news/read/3178950/5-pekerja-asal-tiongkok-ditangkap-di-perusahaan-tambangcianjur

[6] https://news.detik.com/berita-jawa-barat/d-4448270/134-wna-menetap-di-sukabumi-cianjur-hanya-42-orangpunya-e-ktp.

[7] Mohamed, Z. M., Abdul Majid, A. H., \& Ahmad, N. (2010). Tapping new possibility in accounting research, in qualitative research in accounting, Malaysian case. Penerbit Universiti Kebangsaan Malaysia, Kuala Lumpur, Malaysia.

[8] Nasution, Zulkarimein. 1994. Perencanaan program komunikasi. Jakarta. Universitas Terbuka.

[9] Pasal 69 Undang-Undang No 6 Tahun 2011 tentang Keimigrasian.

[10] Pasal 201 Peraturan Pemerintah Nomor 31 Tahun 2013 tentang Peraturan Pelaksanaan Undang-Undang Nomor 6 Tahun 2011 tentang Keimigrasian.

[11] Peraturan Pemerintah Nomor 26 Tahun 2016 tentang Perubahan atas Peraturan Pemerintah Nomor 31 Tahun 2013 tentang Peraturan Pelaksanaan Undang-Undang Nomor 6 Tahun 2011 tentang Keimigrasian.

[12] Peraturan menteri hukum dan hak asasi manusia Republik Indonesia Nomor 50 tahun 2016 tentang Tim pengawasan orang asing.

[13] UU Nomor 6 Tahun 2011 tentang Keimigrasian Pasal 72 (2) kewajiban pemilik penginapan memberikan data mengenai orang asing yang menginap di tempat penginapan.

[14] Yin, Robert K. 1994. Case Study Research. Thousand Oaks, London, New Delhi: SAGE Publications. 